PLANTS PEOPLE

POSSIBILITIES

\title{
Fungi Exotici: XI
}

Author(s): G. Massee

Source: Bulletin of Miscellaneous Information (Royal Botanic Gardens, Kew), Vol. 1910, No. 7 (1910), pp. 249-253

Published by: Springer on behalf of Royal Botanic Gardens, Kew

Stable URL: http://www.jstor.org/stable/4111851

Accessed: 25-06-2016 08:11 UTC

Your use of the JSTOR archive indicates your acceptance of the Terms \& Conditions of Use, available at

http://about.jstor.org/terms

JSTOR is a not-for-profit service that helps scholars, researchers, and students discover, use, and build upon a wide range of content in a trusted digital archive. We use information technology and tools to increase productivity and facilitate new forms of scholarship. For more information about JSTOR, please contact support@jstor.org.

Royal Botanic Gardens, Kew, Springer are collaborating with JSTOR to digitize, preserve and extend access to Bulletin of Miscellaneous Information (Royal Botanic Gardens, Kew) 


\title{
XXXV.-FUNGI EXOTICI : XI.
}

\author{
(With Plates.)
}

\section{G. Massee.}

Of the twelve new fungi here described from material sent to the Royal Botanic Gardens, perhaps the most important is the new species of Eutypa, named E. caulivora, Massee, a parasite on the wood of Hevea brasiliensis, sent for identification by Mr. H. N. Ridley, Director, Botanic Gardens, Singapore.

A new genus, Pilula, Massee, with one species, $P$. straminea, is described from material sent from $\mathrm{N}$ yasaland.

Two other species are of some interest, namely, Sphaerulina Worsdellii, Massee, and Phoma welwitschiae, Massee, as they were found on the dead tips of the leaves of Welvitschia mirabilis, Hook. f., in Damaraland, by Mr. W. C Worsdell.

One species, Nectria theobromicola, which was found on pods of Theobroma cacao, has been named by Mr. C. K. Bancroft.

\section{Agaricaceae.}

\section{Marasmius sordidus, Massee.}

Pileus primo subglobosus dein applanatus, $1 \cdot 5-2 \mathrm{~cm}$. latus, medio umbilicatus, margine primo incurvus grosse sulcatus, sordide fuscescens, glaberrimus. Lamellae decurrentes, utriuque attenuatae, angustae, distantes, pileo concolores, rugis transversis confertis centralibus majoribus stricte lamelloideis concoloribus conjunctae. Stipes erectus vel incurvus, cartilagineus, fistulosus, laevis, glaber, fuscescens, $3 \mathrm{~cm}$. longus, $3 \mathrm{~mm}$. crassus. Sporue ellipsoideae, oblique apiculatae, hyalinae, $5 \times 3 \mu$.

West In Dies. Trinidad : on dead twigs, H. Carracciola, 30.

Allied to Marasmius cubensis, Berk. \& Curt., differing in the narrower, decurrent gills and smaller spores.

Lentinus egregius, Massee.

Pileus profunde infundibuliformis, $12-15 \mathrm{~cm}$. latus, submembranaceus, rigidus, brunneus, ubique squamulosus, margine recto integro ciliato. Jamellae angustissimae, ligneo-albidae, acie integerrimae. Stipes rectus, subteres, sursum incrassatulus, densissime velutinus, fulyescenti-cinnamomeus, 7-9 cm. longus, circa $1.5 \mathrm{~cm}$. crassus. Sporae hyalinae, obliquae, ovoideae, $6 \times 4 \mu$.

Australia. Brisbane: growing on wood, Bailey, 4. Coll. A. J. Boyd.

One of the largest and most beautiful of known species of Lentinus. Most nearly allied to L. velutinus, Fries, which differs in its smaller size, more distant gills, and smaller spores.

Hypholoma Talbotiae, Massee.

Pileus convexus dein applanatus, subumbonatus, circa umbonem depressus, ubique densissime squarroso-squamulosus, purpureus, 3-4 cm. latus. Lamellae postice rotundato-sinuatae, latae, margine crenulatae, dilute violaceae, subdistantes. Stipes teres, minute fistulosus, ad tertium inferum squarroso-squamulosus, sursum glaberrimus, pileo concolor, 4-5 cm. longus, 4-5 mm. crassus. Sporae oblique ellipsoideae, lilacino-tinctae, $6 \times 4 \mu$. 
Tropical Africa. Southern Nigeria: Oban, Mrs. Talbot.

$A$ very beautiful and distinct species, characterised by the purple colour of every part, and by the densely squarrosely scaly pileus and stem.

Lenzites adusta, Massee.

Pileus horizontalis, dimidiatus, antice semi-orbicularis, coriaceosubcartilagineus, plus minusve flexilis, margine subiucurvo acuto, superne dilute brunneo-fumosus, minute adpresseque puberulus vel glabratus sed tactu fere velutinus, $8-9 \mathrm{~cm}$. latus, contextus fibrosus, pallidus. Lamellae subconfertae, ochraceo-flavae, rigidulae, radiantes, usque ad marginem productae. Sporae ellipsoideae, oblique apiculatae, hyalinae, $7 \times 4.5 \mu$.

India. Bengal : on wood, S. Hutchings. Presented by Mr. C. G. Lloyd. Most nearly allied to Lenzites Beckleri, Berk., which is also an Indian species.

\section{Poly poraceae.}

Polyporus indicus, Massee.

Pileus maximus, suborbiculatus, applanatus, irregulariter subconcentrice ac subradiatim undulatus, fissus (an pilei duo pleuroti dorso connati ?), margine acuto, sordide rufo-brunneus, versus marginem aureo-flavidus, glaber, $25-30 \mathrm{~cm}$. diametro ; contex tus suberoso-fibrosus, cinnamomeus, circa $1 \mathrm{~cm}$. crassus. Stipes centralis, breviusculus, crassus, fusco-brunneus. Tubuli gracillimi, ore rotundato-angulato, $1 \mathrm{~cm}$. longi, marginales breviores.

InDIA. Baroda: on the ground, probably attached to buried wood or roots, B. Cavanagh. Presented by Mr. C. G. Lloyd.

A remarkably fine and very distinct species not closely allied to any known form, but suggests affinity with Polyporus Schweinitzii and it; allies.

Polyporus confusus, Massee.

Pileus coriaceus, tenax, glaber, infundibuliformis, rubro-brunneus vel gilvus, 5-6 cm. latus. Stipes centralis, rectus vel incurvus, circa $2 \mathrm{~cm}$. longus. Pori curti, minuti, inaequales, decurrentes, cinnamomeo-lutescentes, pallidi. Sporae cylindraceo-ellipsoideae, utrinque subacutae, hyalirae, 12-14 × 4-5 $\mu$.

North A merica. Louisiana: on wood, J. B. Ellis, 6007.

This species superficially closely resembles Polyporus craterellus, Berk. \& Curt., differing more especially in the elongated spores. In $P$. craterellus the spores are sub-globose, averaging $5 \times 4 \mu$. This feature of distinction was detected by Mr. G. C. Lloyd, who is now engaged in a critical study of the Polyporeae in the Kew Herbarium.

\section{Sphaeriaceat.}

Nectria theobromicola, Bancroft.

Perithecia gregaria, globosa, salmonicoloria, hy pothallo aurantiaco insidentia, 280-300 $\mu$ diametro. Asci cylindraceo-clavati, breve stipitati, octospori, $80-90 \times 8-10 \mu$, paraphysibus filiformibus obvallati. S'porae distichae vel monostichae, elliptico-oblongae, utrinque obtusae, 1-septatae, ad septum constrictae, 16-20 $16 \mu$. 
Kew Bulletin, 1910.

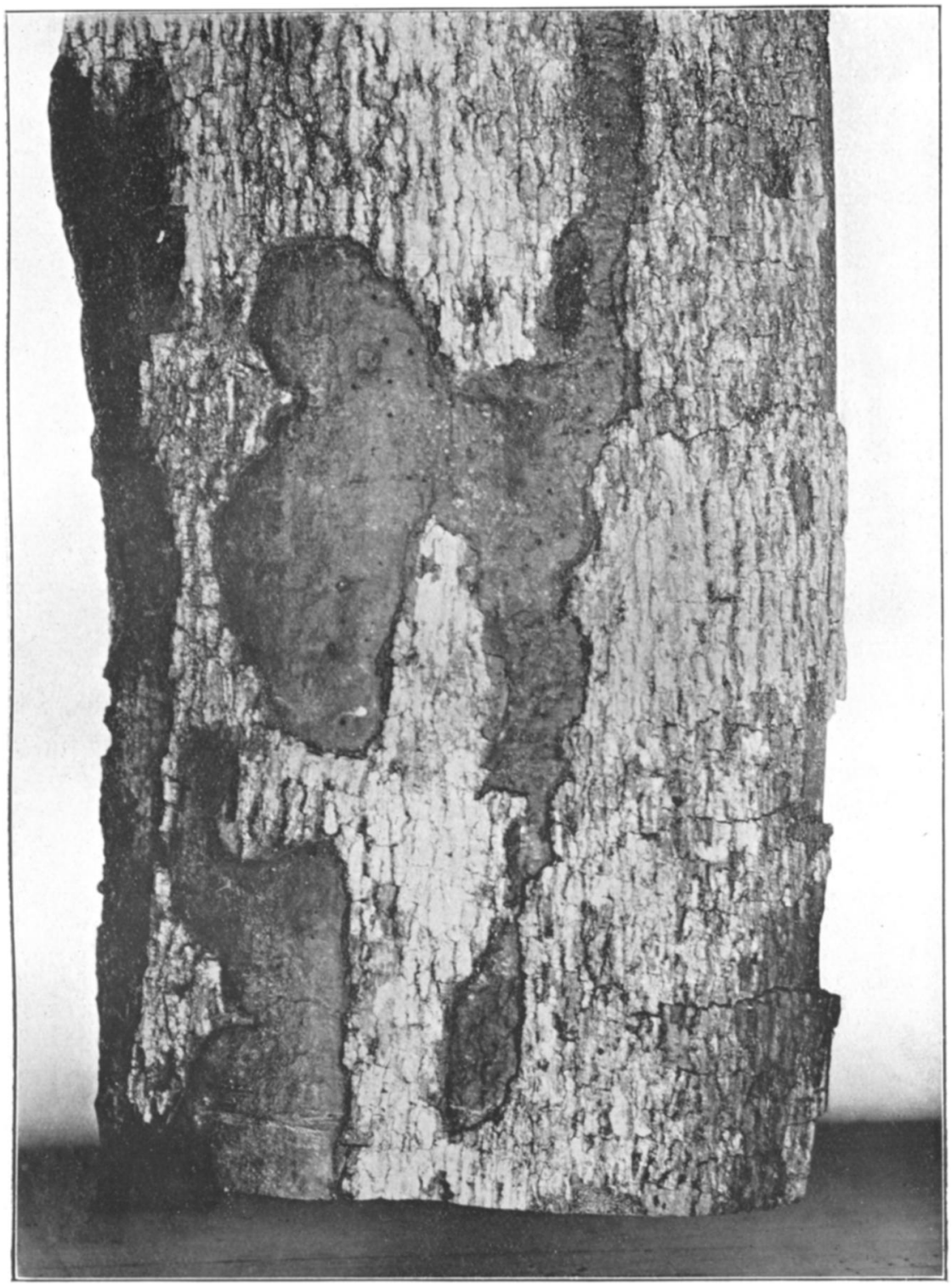

Eutypa CaUlivora.

Stroma on trunk of Hevea brasiliensis.

[To face page 250.

This content downloaded from 159.178.22.27 on Sat, 25 Jun 2016 08:11:01 UTC All use subject to http://about.jstor.org/terms 


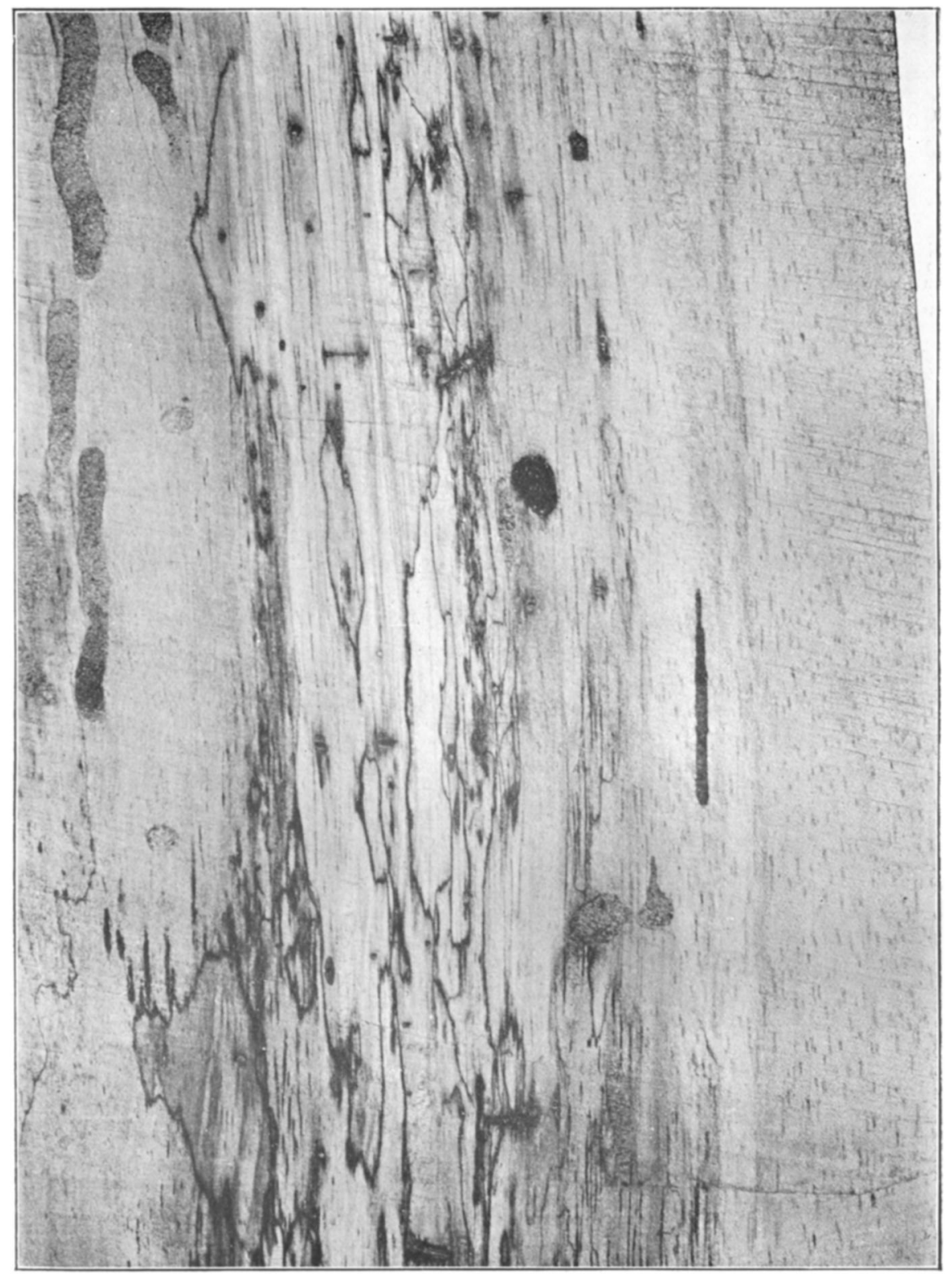

\section{Eutypa caulivora.}

Section of trunk showing dark lines formed by the mycelium in the wood.

[To face page 251 . 
Tropical Africa. Received from West Africa on pods of Theobroma cacao, which were also attacked by Diplodia cacaoicola, P. Henn.

Eutypa caulivora, Massee in Agric. Bull. Str. and F. M. States, ix. 217 (nomen).

Stroma latissime effusum, innatum dein superficiale, e ligno nigrefacto efformatum, extra intusque nigrum. Perithecia densissime stipata, ovoidea, ostiolo breviusculo atro stromatis superficiem vix attingente donata. Asci cylindraceo-clavati, parte sporifera subfusoidea, aparaphysati, octospori. Sporae ellipsoideae, utrinque obtusatae, hyalinae vel dilute chlorinae, 32-35 × 9-11 $\mu$.

MAl.AY. Singapore : Botanic Garden, H. N. Ridley.

Forming numerous large black blotches on the trunk of a specimen of the Para rubber tree-Hevea brasiliensis, Muell.-Arg. Other species of Eutypa, as E. erumpens, Mass., and E. gigaspora, Mass., are destructive parasites to timber trees, and undoubtedly $\boldsymbol{E}$. caulivora is a tree parasite, although the fruit of the fungus only appears on the surface of the trunk when the tree is dead. A section of the trunk shows the dark lines formed by the mycelium of the fungus extending quite to the centre, and proves that in the example under consideration the fungus had been present in the tissues for some considerable time previous to the death of the tree. Death ensued from starvation, owing to the water supply from the root being checked by the copious development of mycelium in the water-conducting tissue. It is highly probable that the fungus occurs on indigenous trees, and has passed from thence to the cultivated rubber trees, which, judging from the material received, prove to be admirably adapted to meet the requirements of the parasite. A careful search for the presence of this fungus on indigenous trees should be made, and its extermination attempted, if discovered in localities where the establishment of a rubber plantation is contemplated.

An account of this fungus has been published in the Agricultural Bulletin of the Straits and Federated Malay Straits, ix, pp. 216-218, from which the following paragraph by the editor is taken.

"On two or three occasions we had observed that on dead trunks of Para rubber trees, after being untouched for some weeks, the outer corky layer of bark split off in flakes and beneath appeared large black patches of a fungus.

"This fungus was in the form of a crust, black, hard and rather brittle, about $1-3$ inch thick, and looking like dried tar or asphalt. It formed rather irregular patches of various sizes from one to ten inches across, the edges of the patches being rounded, and the mass usually longer than broad. In one tree about 25 years old and about two feet through, there were no previous signs of any disease but the tree rather suddenly died and the fungus came out on the wood some weeks later. Since then the next tree to it has died, much in the same way as if it had been killed by Fomes, but it was not attacked by that. On removing the stump we found that just below the tree was an accumulation of foul-smelling water. The roots of the tree were quite dead. Several other trees in this part of the garden, but at some little distance, died in a somewhat similar manner. None of these, however, so far as I remember 
except the first-mentioned one, showed any sign of the fungus after death, and indeed on seeing the foul putrid mass of water and decayed sticks in which the trees' roots had been living, I was more surprised that they had lived so long than that they had died.

"A About the end of last year, a small tree eight inches through in another part of the garden was overset with several others by a gale and its roots were badly broken. It was replaced in position but never recovered and remained erect, but dead for some time.

"It then developed the fungus in several parts of the stem from about 5 feet downwards."

\section{Sphaerulina Worsdellii, Massee.}

Perithecia late gregaria, globoso-lenticularia, epidermide velata, membranacea, atra, contextu densiuscule parenchymatico fuligineo, ostiolo vix papillulato donata, 120-130 $\mu$ diametro. Asci aparaphysati, rotundati, crassiuscule tunicati, octospori. Sporae cylindraceo-clavatae, hyalinae, diu 1-septatae, demum 3-septatae, 24-25 $\times$ 8-9 $\mu$.

Tropical Africa. Damaraland : near Welwitsch; on the dead tips of leaves of Welvitschia mirabilis, Hook. f., $W$. $C$. Worsdell.

\section{Pilula, Massee; gen. nov.}

Perithecia superficialia, globosa, astoma, membranacea, glabra, pallida. Asci elongato-fusoidei, octospori, aparaphysati. Sporuc ellipsoideae, 1-septatae, hyalinae.

Superficially this genus closely resembles Eurotium in the pale coloured, superficial, astomous perithecia, but differs markedly in the elongated asci and the elliptical, 1-septate spores.

Pilula straminea, Massee.

Perithecia dense gregaria, minuta, 180-200 $\mu$ diametro, glabra, laevia, straminea, contextu parenchymatico pellucido in sicco cupulato-collapsa, mycelio tenuissimo effuso insidentia. Asci elongatofusoidei, in stipite longiusculo attenuati, cito diffluentes, 85-90 $\times$ 12-15 . Sporae ellipsoideae, utrinque subacutae, 1-septatae, ad septum non constrictae, hyalinae, 12-15 $\times 6 \mu$.

Tropical Africa. Nyasaland: Zomba; appeared in quantity on some cotton wool or similar substance used for packing fungi, J. Stewart J. Mc Call.

Forming a densely gregarious patch of minute straw-coloured, globose perithecia, indistinguishable under a lens from Eurotium.

\section{'I'Uberaceae.}

\section{Elaphomyces sapidus, Massee.}

Ascomata subglobosa, indurata, atrobrunnea, minutissime verruculosa, basi manifeste nulla, fibris radicalibus destituta, $3-5 \mathrm{~cm}$. diametro. Sporae globosae, episporio ubique majuscule verrucoso, saturate olivaceo-brunneae, 12-16 $\mu$ diam.

In D IA. United Provinces, I. H. Burkill, 29,518.

An edible species, eaten by the natives. Approaching Elaphomyces papillatus, Vitt., in the minutely warted peridium, but differing markedly in the larger, coarsely warted spores. 


\section{Sphaeropgidiaceae.}

Phoma welwitschiae, Massee.

Perithecia erumpenti-superficialia, dense aggregata, hemispherica, atra, contextu dense parenchymatico fuligineo, ostiolo minuto pertuso, 150-180 $\mu$ diametro. Conidia elliptica, utrinque obtusiuscule rotundata, grosse 2-guttulata, hyalina, $5 \times 3 \mu$, sterigmatibus simplicibus fulta, $8-10 \times 1.5 \mu$.

Tropical Africa. Damaraland : near Welwitsch; on the dead tips of leaves of Welwitschia mirabilis, Hook. f., $W . C$. Worsdell.

The perithecium is exceptionally thick and dense, and the ostiolum or pore is very minute. The conidia are involved in mucus which sets hard when dry, but dissolves and swells very much when moistened and is extruded through the ostiolum carrying the conidia along with it. In every respect the fun ${ }^{\prime}$ us is as xerophytic as its host.

\section{XXXVI.-MISCELLANEOUS NOTES.}

Mr. C. K. Bancroft, B.A., formerly Major Scholar of Trinity College, Cambridge, has been appointed by the Sec:retary of State for the Colonies, on the recommendation of Kew, Assistant Mycologist in the Federated Malay States.

Mr. Albert Richard Goved, a member of the gardening staff of the Royal Botanic Gardens, has been appointed by the Secretary of State for the Colonies, on the recommendation of Kew, a Curator in the Agricultural Department of the Gold Coast in succession to Mr. J. Anderson (K.B. 1905), resigned.

Mr. Will.iam Leslie WoOd, lately a member of the gardening staff of the Royal Botanic Gardens, has been appointed by the Secretary of State for the Colonies, on the recommendation of Kew, Superintendent of Government Plantations in the Federated Malay States in succession to Mr. F. R. Long (K.B. 1908, 195), resigned.

Mr. L. Lew'ton-Brin. We learn that Mr. Lewton-Brain formerly Mycologist and Lecturer in Agriculture to the Imperial Department of Agriculture for the West Indies (K.B. 1903, 30), and afterwards Assistant Director in the Division of Physiology and Pathology in the experiment station of the Hawaiian Sugar Planters' Association, has been appointed Director of Agriculture in the Federated Malay States in succession to Mr. W. J. Gallagher (K.B. 1909, 342), resigned. 